\section{Lichens under threat from ash dieback}

The fungal pathogen Chalara

fraxinea is killing ash trees

(Fraxinus excelsior) throughout Europe. Also potentially under threat is the large diversity of lichens that these ash trees support.

Using data from the UK National Biodiversity Network (www.nbn.org.uk), we found 536 lichen species (corresponding to some $30 \%$ of UK lichens) that occur on ash. Of these, 84 are categorized as under threat in Britain using International Union for Conservation of Nature standards.

For at least six of these threatened species, more than half of the records in the database are for specimens found on ash trees. This includes Fuscopannaria ignobilis, a lichen that receives the highest UK legislative protection status under Schedule 8 of the 1981 Wildlife and Countryside Act, and Wadeana dendrographa, for which the United Kingdom has international conservation responsibility.

Ash, along with non-native tree species such as sycamore (Acer pseudoplatanus), provided an alternative host for lichens affected by the catastrophic decline of elm trees during the 1970s. If the UK ash population succumbs to dieback, the rescue effect for lichens is a consideration that should influence landscape management of non-native trees.

Christopher J. Ellis, Brian

J. Coppins, Peter M.

Hollingsworth Royal Botanic

Garden Edinburgh, UK.

c.ellis@rbge.org.uk

\section{NIH chimps: don't sell sanctuary short}

You quote Kathy Hudson, deputy director for science, outreach and policy at the National Institutes of Health (NIH), as saying: "In a perfect world, we would absolutely like to move all of the [retiring laboratory] chimps directly to Chimp Haven [sanctuary]" (Nature 491, 18; 2012). This fails to acknowledge the NIH's legal mandate to do just that.

Since the passage of the Chimpanzee Health Improvement Maintenance and Protection (CHIMP) Act 12 years ago, the NIH has done less than right by the law and by its research chimps in allowing labs to make discretionary decisions about the animals' retirement. It claims not to have sufficient funding to provide housing for retired chimps at the federal sanctuary, while financing the expansion of labs to accommodate chimps.

The CHIMP Act obliges the $\mathrm{NIH}$ to provide lifetime care for retired chimps. The agency's fiscal-reserve cap does not restrict it from finding more funds to fulfil its mandate, or limit its responsibility to do so. Meanwhile, the federal sanctuary should not be going short. Theodora Capaldo New England Anti-Vivisection Society, Boston, Massachusetts, USA. theodoracapaldo@neavs.org

\section{NIH chimps: use existing facilities}

Louisiana's Chimp Haven sanctuary for retired laboratory chimpanzees is requesting a further US\$2.55 million from the National Institutes of Health (NIH) to construct housing for 110 chimps about to retire from the New Iberia Research Center, part of the University of Louisiana at Lafayette (Nature 491, 18; 2012). However, the sanctuary has almost hit the $\mathrm{NIH}$ funding cap of $\$ 30$ million, and other facilities are already available at the Texas Biomedical Research Institute's Southwest National Primate Research Center (SNPRC), of which I am director.

The housing at the SNPRC is cost-effective, high quality and similar to some housing at
Chimp Haven. The SNPRC also provides extensive enrichment programmes for the animals.

Besides housing, the NIH needs to consider the pressing health-care needs of ageing chimps and the capacity of institutions to meet them.

The SNPRC's medical capabilities are state-of-the-art. For example, four veterinarians are employed for 141 chimps, compared with one for 130 chimps at Chimp Haven. Veterinarians at the SNPRC have 90 years' combined experience working with chimps. And the SNPRC has an on-site pathology lab equipped for testing within minutes of a medical emergency, a facility not available at Chimp Haven.

Given that the vacant facilities at the SNPRC were partly funded by a $\$ 1.5$-million grant from the NIH, the proposed allocation of scarce federal research dollars to duplicate them at Chimp Haven seems wasteful. The Congressional Budget Office has estimated that the cost to the taxpayer of transferring the New Iberia animals and 330 other NIH-owned chimps to Chimp Haven would be $\$ 56$ million over the next 5 years alone.

John L. VandeBerg Texas Biomedical Research Institute and Southwest National Primate Research Center, San Antonio, Texas, USA.

jlv@txbiomedgenetics.org

\section{NIH chimps: Texas lab is not a sanctuary}

As a physician who provided testimony for the US Institute of Medicine report that found chimpanzee experiments to be scientifically unnecessary, I am thrilled that the National Institutes of Health has declared some 110 of its chimps ineligible for research (Nature 491, 18; 2012).

But sending any of these chimps to the Texas Biomedical
Research Institute in San Antonio, even for the short term, is no retirement. Laboratories are designed to facilitate research, not to provide high-quality, longterm care for chimps, which are cognitively, socially and emotionally complex animals.

Furthermore, the Texas Biomedical Research Institute was fined more than US\$25,000 by the US Department of Agriculture in December 2011 for violations of the Animal Welfare Act after three animals escaped from their cages (see go.nature.com/dnzsqa). John Pippin Physicians Committee for Responsible Medicine, Washington DC, USA. jpippin@pcrm.org

\section{Cuts endanger young scientists in Europe}

The Young Academy of Sweden has joined forces with the Young Academies of Germany, the Netherlands and Denmark to urge the leaders of the European Union to invest more, not less, in science in their upcoming budget (see go.nature.com/ ymjole). Short-term savings would have long-term costs and weaken Europe's future scientific standing.

The academies' members are especially concerned that cuts could target the European Research Council (ERC), which has emerged as a funding model for junior researchers in highprofile international science.

The ERC provides these young scientists with the funding to develop their own lines of research, rather than relying on the patronage of a senior colleague. This strategy encourages promising scientists to stay in Europe and others to return from abroad. It also attracts research talent from around the world.

Christian Broberger, Anna Sjöström Douagi The Young Academy of Sweden, Stockholm, Sweden. asd@sua.kva.se 